\section{Identification of frequently consumed commercially prepared ready-to-eat foods and beverages in}

\section{Bangladesh}

\author{
Sohel Reza Choudhury', Abu Ahmed Shamim', Nazma Shaheen², Nisarga \\ Bahar ${ }^{1,2}$, Sneha Sarwar, ${ }^{12}$, Md Musharraf Ashraf', Mohammad Abdullah Al \\ Mamun', Sheikh Mohammad Mahbubus Sobhan', Md Joynul Abedin², Kabir \\ Hossen ${ }^{3}$, Mohammad Robed Amin ${ }^{4}$, Abdul Alim ${ }^{4}$
}

Bioresearch Communications

Volume 7, Issue 2, July 2021

DOI:

https://doi.org/10.3329/brc.v7i2.54377

\footnotetext{
${ }^{1}$ National Heart Foundation Hospital \& Research Institute, Plot 7/2, Section 2, Mirpur, Dhaka 1216

${ }^{2}$ Institute of Nutrition and Food Science, Dhaka University, Dhaka 1000, Bangladesh

${ }^{3}$ CIPRB- a Centre for Injury Prevention and Research, Mohakhali, Dhaka, Bangladesh

${ }^{4}$ Non-Communicable Disease Control (NCDC) Programme, Directorate General of Health Services (DGHS), Mohakhali, Dhaka-1212.
}

\begin{abstract}
Ready-to-eat processed foods and beverages are eaten without further cooking or processing. These are generally energy-dense and contain a high amount of saturated fat, sodium, and added sugar. The consumption pattern of these foods varies regionally, seasonally, and agewise. The present study aims to identify commercially prepared ready-to-eat processed foods and beverages frequently consumed by different age groups in rural and urban areas of Bangladesh during the month of Ramadan and the non-Ramadan period. In this cross-sectional study, 948 individuals from 480 households in all eight administrative divisions of Bangladesh were interviewed during the month of Ramadan and the NonRamadan period. We identified puffed rice, peyaju, chanachur, chips, unbranded ice cream to be the overall highly consumed foods, consumed by $46.3,40.1,39.638 .0$, and 33.1 percent respondents, respectively. Consumption of foods other than puffed rice was significantly different across the age groups $(p<0.05)$. A significantly higher number of respondents consumed puffed rice, deep-fried foods (peyaju, beguni, jilapi), and branded ice cream during Ramadan as compared to the non-Ramadan period $(p<0.05)$. It was also found that the overall consumption rate of packaged items was higher among the urban population as compared to the respondent living in rural areas. When the foods were scored according to their consumption rate stratified by age, fasting, and regions, puffed rice, chips, chanachur, unbranded ice cream, peyaju were found to be top foods. Considering frequent intake of processed foods their nutrient composition should be analyzed to know their healthiness.
\end{abstract}

KEYWORDS: Ready-to-eat foods, nutrition, salt, sugar, saturated fat, trans fats, Bangladesh.

RECEIVED: 12 March 2021, ACCEPTED: 07 June 2021

TYPE: Original Research
CORRESPONDING AUTHOR: Dr. Sohel Reza Choudhury, Department of Epidemiology \& Research, National Heart Foundation Hospital \& Research Institute, Email: sohel_r_choudhury@hotmail.com

\section{Introduction}

Ready-to-eat (RtE) foods are defined as foods that are made by various rigorous processing systems in a way that they are consumed in the state as purchased i.e. foods and beverages that can be purchased directly from the neighborhood grocery stores or hawkers or at local markets and are eaten without cooking or further processing (National Health and Medical Research Council, 2013; Poti et al., 2016). In the South Asian context, most RtE foods are considered junk foods, as these foods are mostly unhealthy and contain a high amount of added sugar, salt, saturated and trans fats. They are also poor in health-promoting nutrients such as vitamins, minerals, and dietary fibers (Gupta et al., 2019a). RtE foods include processed foods manufactured and sold in packages with nutrition labels by food processing enterprises, as well as foods freshly prepared at restaurants and sold without any nutrition information. Previous studies demonstrated that most processed RtE foods are highly energy-dense and contains a high amount of saturated fat, sodium, and added sugar
(Slimani et al., 2009; National Health and Medical Research Council, 2013; Watson et al., 2016).

In developed countries, consumption of processed foods and beverages accounts for about two-thirds of daily required energy (Slimani et al., 2009). Interestingly, an increasing trend in the consumption of processed foods is also observed in low and middle-income countries (Stuckler et al., 2012; Baker and Friel, 2016). For instance, a study reported that consumption of energy-dense processed food such as packaged snacks, beverages, deep-fried savory foods, sweetened confectionery is persistently increasing in Bangladesh (Imamura et al., 2015). It was also reported that caregivers in Bangladesh introduce RtE foods even to under two-year-old children (Jannat et al., 2020).

Studies carried out all over the world demonstrated the association of processed food consumption with overweight, obesity, and non-communicable diseases (Gupta et al., 2019b). For instance, a 2018 study in the USA found that consumption 
of processed fried foods significantly increased the risk of mortality from cardiovascular diseases (CVD) among women (Sun et al., 2019). Prospective cohort studies also demonstrated that frequent consumption of fried foods was associated with an increased risk of cardiovascular morbidity and type 2 diabetes (Cahill et al., 2014; Djoussé, Petrone and Michael Gaziano, 2015; Sun et al., 2019). In Bangladesh, the death rate due to non-communicable diseases such as cardiovascular disease, cancer, diabetes is increasing at a high rate (Directorate General of Health Services, 2011). Among the South Asian countries, Bangladesh has a high rate of CVD and least in action against it (Department of Public Health and Primary Care, 2013). Identification of unhealthy RtE processed foods and their consumption patterns in Bangladesh will facilitate the formulation of the guidelines to mitigate the adverse health effects of RtE processed food.

In Bangladesh, the identification of commonly consumed processed foods and evaluating their healthiness has not been undertaken using nationally representative samples. In this newly growing consumer economy having a short time for food preparation and vast food choices, the identification and determination of the consumption rate of these products is important for further analysis of their nutritional composition and healthiness as well as their association with diet-related non-communicable diseases.

The purpose of this study is to identify the commonly consumed processed foods and beverages in rural and urban areas across different ages in different periods (Ramadan and non-Ramadan) in Bangladesh.

\section{Methods}

The cross-sectional study was conducted through a household survey. Four teams, each comprising a supervisor and two enumerators, were employed for data collection. The data collection teams received a 5-day long training, including two days of field practice. The field research associates collected food consumption data using tabs (Samsung Galaxy Tab A, Model number: SM-T285), using REDCap (Research Electronic Data Capture) software.

Data were collected from all 8 administrative divisions of Bangladesh. Two rural clusters and one urban cluster were randomly selected from randomly selected districts of each division. In Total, 480 households were surveyed from 24 survey clusters and information about 948 individuals was collected. Two respondents from each household were interviewed. However, no more than one member in the same age category was interviewed from one household. Information about socio-demographic characteristics, dietary intake (7-day food frequency), usual eating behavior, were also gathered. The interviewers asked the respondents "in the last seven days, how many days and times (frequency) did you eat (name of $30 \mathrm{RtE}$ foods described in the questionnaire)?"; at the end of the interview, the interviewers also asked about any other RtE foods not mentioned in the questionnaire and recorded their names and consumption frequency. Information on food intake for pre-school children were obtained from mother or caregiver.

\section{Statistical analysis and identification of commonly consumed ready-to-eat foods}

Data were analyzed using SPSS version 20.0 and Microsoft Office Excel 2007. Intake of RtE foods are reported by age (four categories), residence (rural-urban), and period of data collection (Ramadan fasting month and non-fasting month). Data were reported as the percentage of the total population. Association between variables was analyzed with a chi-square test at a significance level $\mathrm{p}<0.05$.

Foods were grouped under categories described by World Health Organization (WHO, 2021). Sugar-sweetened beverages (SSB) are defined as drinks that contain added sugars as proposed by the CDC (CDC, 2010). Sweet foods included traditional dairy-based sweets (Ranganadham M., Sathish Kumar M. H., Devraja H. C., 2016) and other foods with added sugar. Table-1 describes some commonly consumed commercially produced RtE processed foods in Bangladesh.

The overall consumption percentage was calculated for $33 \mathrm{RtE}$ foods among the four age categories as preschool children (2 to 5 years of age), school going children (6 to 9 years of age), adolescents (10 to 19 years of age), and adult ( $\geq 20$ years of age) and cross-tabulated. Next, a separate calculation was performed to determine the foods most consumed during the month of Ramadan. A similar calculation was also carried out using data collected during the non-Ramadan period to identify the most consumed RtE foods during this time. The consumption pattern in urban and rural areas during the month of Ramadan and the non-Ramadan period was then calculated. Identification of the most frequently consumed foods was done using a scoring system based on the proportion of participants in different categories consumed the food and is described in Supplementary Table 1. Foods were scored for each category (Age groups consumption, urban consumption, rural consumption) before and during Ramadan. For each of the above categories, the top foods were calculated by percentage consumptions and arranged in descending order. First, we scored the most frequently consumed 27 RtE foods and beverages by assigning the most consumed food a score of 27 , and 26 to the next one and so on for each food and beverage. As a result, we found the top scores for age groups (4 categories), urban population, and rural population, as well as for both Ramadan and Non-Ramadan seasons. The scores obtained by all of the categories were then added to achieve a final score. Then the 24 foods which obtained the highest score both in Ramadan and in Non-Ramadan month were arranged in descending order. 
Table 1. List and description of most commonly consumed RtE processed foods and beverages.

\begin{tabular}{|c|c|}
\hline Name of samples & Description \\
\hline \multicolumn{2}{|c|}{ Ready to eat savory (salty and spicy, but not sweet) snacks } \\
\hline Chips & $\begin{array}{l}\text { Chips are a form of deep-fried potato which is crispy and spicy and } \\
\text { generally sold in a plastic packet and produced by various national } \\
\text { brands and local producers. }\end{array}$ \\
\hline Fried pulses/peas & $\begin{array}{l}\text { These are RtE fried peas and pulse which are sold in small plastic } \\
\text { packages. }\end{array}$ \\
\hline Chanachur & $\begin{array}{l}\text { Chanachur is made by mixing various ingredients such as wheat or } \\
\text { pulse flour chips, fried peas, peanuts, rice, spices, etc. }\end{array}$ \\
\hline \multicolumn{2}{|l|}{ Baked products } \\
\hline Biscuits & $\begin{array}{l}\text { Biscuit is a dried baked snack made out of dough and usually crispy, } \\
\text { flat. They can be either sweet or salty. This popular snack is sold in } \\
\text { both packet and open form in Bangladesh. }\end{array}$ \\
\hline Cake & $\begin{array}{l}\text { Cakes are baked food made from mixing flour, sugar, eggs, baking } \\
\text { powder, etc. The branded cakes are wrapped in a plastic package and } \\
\text { non-branded cakes are wrapped in thin transparent polythene. }\end{array}$ \\
\hline \multicolumn{2}{|c|}{ Sugar-sweetened beverages and Ice-cream } \\
\hline Soft drink & $\begin{array}{l}\text { Soft drinks are also called non-alcoholic beverages which are usually } \\
\text { carbonated and contain sugar or artificial sweeteners and flavorings. }\end{array}$ \\
\hline Energy drink & $\begin{array}{l}\text { An energy drink is also a form of beverage that contains a stimulant like } \\
\text { caffeine. They are usually non-carbonated and sometimes carbonated } \\
\text { and may use sugar or sweetener and other flavorings. }\end{array}$ \\
\hline Fruit drink & $\begin{array}{l}\text { Fruit drinks are non-alcoholic, usually carbonated, sweetened beverages } \\
\text { made of concentrated fruit pulp and flavor and color. }\end{array}$ \\
\hline Chocolate & $\begin{array}{l}\text { Chocolates are confectionery items produced from roasted and ground } \\
\text { processed cacao beans. Some milk chocolates are said to have mixed } \\
\text { milk powders. }\end{array}$ \\
\hline Lozenge/ Lollipop & $\begin{array}{l}\text { Lozenge and lollipops are sweetened and flavored confectionery items } \\
\text { that are made from milled sugar dough and sold in solid form in small } \\
\text { plastic packages. }\end{array}$ \\
\hline Ice-cream & $\begin{array}{l}\text { Ice-creams are very popular frozen items. It is soft, sweet, creamy, and } \\
\text { made with milk and whipped cream, and also flavored with vanilla, } \\
\text { chocolate, fruit, or other components. }\end{array}$ \\
\hline \multicolumn{2}{|c|}{ Deep-fried savory snacks and sweetmeats } \\
\hline Peyaju & $\begin{array}{l}\text { Prepared at home, restaurants, and also by roadside vendors. Pulse is } \\
\text { soaked overnight and ground into a past or pulse flour (sometimes } \\
\text { mixed with wheat or rice flour) and made into a paste by mixing with } \\
\text { water. This paste is mixed with onion, green chili, spices, and lumps of } \\
\text { this paste is deep-fried in oil and usually consumed hot. }\end{array}$ \\
\hline Singara/Samosa & $\begin{array}{l}\text { Singara/Samosas are fried savory snacks which contain ingredients } \\
\text { such as spiced potatoes, onions, peas, meats, or lentils stuffed in a } \\
\text { triangular or cone-shaped flour shell. }\end{array}$ \\
\hline Puri & $\begin{array}{l}\text { Puri is a deep-fried savory snack produced with wheat flour (locally } \\
\text { known as atta or maida) with a round bread-like shape. Usually, mashed } \\
\text { potatoes or pulses (mashed with turmeric powder, salt, and spices) are } \\
\text { stuffed between the bread. }\end{array}$ \\
\hline Beguni & $\begin{array}{l}\text { Beguni is a form of deep-fried eggplant coated with beson (pulse flour } \\
\text { such as ground chickpea) mixed with salt and spices such as turmeric, } \\
\text { pepper, baking soda, etc. }\end{array}$ \\
\hline Jilapi (or Jilabi) & $\begin{array}{l}\text { Jialpi is a very popular deep-fried sweet-savory snack. It is made with } \\
\text { flour (maida) and butter mixed with baking soda and sometimes with } \\
\text { Safran color in a twisted round shape. After frying, it is soaked in sugar } \\
\text { syrup. Sometimes lime juice or yeast is used. }\end{array}$ \\
\hline
\end{tabular}




\begin{tabular}{|c|c|}
\hline Rasogolla/Golapjam/Kalojam & $\begin{array}{l}\text { Rosogolla is a kind of sweetmeat made from dough and cottage cheese } \\
\text { which is formed into balls with starch or flour and cooked in sugar } \\
\text { syrup. Golapjam/Kalojam are similar products, which are first fried in } \\
\text { oil and then cooked in sugar syrup. }\end{array}$ \\
\hline Chola & $\begin{array}{l}\text { Chickpea soaked overnight or boiled until soft and fried with spices, } \\
\text { onions, green chili, and potatoes are generally added. }\end{array}$ \\
\hline \multicolumn{2}{|c|}{ Ready-made and convenience foods and composite dishes } \\
\hline Instant noodles & $\begin{array}{l}\text { Noodle is a very popular processed food made of unleavened dough in } \\
\text { a long stretched string form. Instant noodles generally require brief } \\
\text { cooking, are also consumed as snacks by children without further } \\
\text { processing. }\end{array}$ \\
\hline $\begin{array}{l}\text { Pizza/Burger/ Sandwich/ Chicken } \\
\text { Nugget }\end{array}$ & $\begin{array}{l}\text { Pizza is a composite dish and consists of a round dough base baked } \\
\text { with various toppings like cheese, tomatoes, vegetables, meat, etc. } \\
\text { The burger consists of cooked patties of ground or minced meat and } \\
\text { other ingredients like cheese and toppings. The patties are usually fried, } \\
\text { grilled, or smoked. } \\
\text { The sandwich is a food typically eaten as a light breakfast consists of } \\
\text { sliced meats, cheese, eggs or vegetables between two slices of bread. } \\
\text { Chicken nugget is a deep-fried or baked product that contains small } \\
\text { pieces of chicken and is coated with batter }\end{array}$ \\
\hline Pastry/Cream roll & $\begin{array}{l}\text { The pastry is a kind of baked product made of various ingredients such } \\
\text { as flour, eggs, sugar, baking powder, milk, butter, shortening, etc. with } \\
\text { a cream or jam filling. } \\
\text { A cream roll is a kind of puff pastry sheet filled with whipped cream. }\end{array}$ \\
\hline \multicolumn{2}{|l|}{ Others } \\
\hline Chutney & $\begin{array}{l}\text { It is a kind of condiment made with fruits and vegetables mixing with } \\
\text { spices, vinegar, and sugar. }\end{array}$ \\
\hline Puffed rice (Muri) & $\begin{array}{l}\text { Muri is a type of puffed rice known mainly as a breakfast cereal. The } \\
\text { puffed rice mixed with spices and sauce is very popular street food in } \\
\text { Bangladesh. }\end{array}$ \\
\hline
\end{tabular}

\section{Ethical approval}

This study received ethical approval from the Institute of Health Economics of the University of Dhaka. Written informed consent was obtained from respondents (adults) or legal guardian of adolescents and children.

\section{Result}

\section{General Characteristics of the interviewers}

During the field survey, information about 480 households was collected from both of the primary caregivers (head of the household and his/her spouse), thus totaling 948 respondents. Among the respondents, $65.7 \%$ were aged between 31 to 50 years. Almost all of them $(97.9 \%)$ were married. $22.5 \%$ of the respondent never attended school, 36.5\% of them only completed primary education. $6.2 \%$ of the respondents were unemployed, while a major portion of the respondents $(43.1 \%)$ identified themselves as home-makers, and $26.9 \%$ of them were wage earners. Table 2 shows the socio-demographic characteristics of the primary caregivers of the household. 
Table 2. Socio-demographic characteristics of the respondents of the household

\begin{tabular}{|c|c|c|}
\hline \multicolumn{2}{|l|}{ Characteristics } & $\mathrm{N}(\%)$ \\
\hline \multirow[t]{2}{*}{$\operatorname{Sex}$} & Male & $478(50.4)$ \\
\hline & Female & $470(49.6)$ \\
\hline \multirow[t]{4}{*}{ Age } & 2years to 5years (Preschool) & $236(24.9)$ \\
\hline & 6 years to 9 years (School going child) & $235(24.8)$ \\
\hline & 10 years to 19 years (Adolescent) & $242(25.5)$ \\
\hline & 20years or above (Adult) & $235(24.8)$ \\
\hline \multirow[t]{4}{*}{ Education } & Never went to school & $333(35.1)$ \\
\hline & Up to primary & $370(39.0)$ \\
\hline & Up to secondary & $208(21.9)$ \\
\hline & Higher secondary or above & $37(3.9)$ \\
\hline \multirow[t]{6}{*}{ Occupation } & No occupation/Student & $709(74.8)$ \\
\hline & Wage-earners & $66(7.0)$ \\
\hline & Business Holders & $35(3.7)$ \\
\hline & Home-maker & $113(11.9)$ \\
\hline & Service holder & $17(1.8)$ \\
\hline & Others & $8(0.8)$ \\
\hline
\end{tabular}

\section{Consumption of commonly consumed ready-to-eat processed foods}

Table 3 shows the consumption of RtE processed foods by different categories of the respondents. Among the total respondents, highly consumed foods were puffed rice (46.3\%), peyaju $(40.1 \%)$, chanachur (39.6\%), chips $(38 \%)$, unbranded ice cream (33.1\%), beguni (30.9\%), jilapi (30.9\%), chocolate/lollipop/lozenge (28.7\%), unbranded cake (24.9\%), and large biscuit (24.8\%). It was also observed that consumption of chips, chanachur, fried pulse, small packet biscuit, unlabeled cake, chocolate/lollipop/lozenge, soft drink, energy drink, fruit juice, ice cream (unbranded and branded), piyaju, chutney, chola, pizza significantly varied across different age groups $(\mathrm{p}<0.05)$. Comparatively high consumption of cake, roshgolla, chocolate lozenge lollipop was observed among pre-school children. Chips, chanachur, fried peas and pulse, chutney, fruit juice, unbranded ice cream were the preferred items for school-going children. Branded ice cream, soft drinks, energy drinks, puffed rice, peyaju, beguni, burgers were highly consumed by adolescents. Puri, Alur chop, jilapi were the preferences of adult respondents.

Table 3. Percent of respondents consumed RtE processed foods and beverages at least once during the week preceding the interview

\begin{tabular}{|c|c|c|c|c|c|c|}
\hline \multirow{2}{*}{$\begin{array}{l}\text { Process Food } \\
\text { Name }\end{array}$} & \multicolumn{4}{|c|}{ Number (percent) of respondents } & \multirow{2}{*}{$\begin{array}{l}\text { Total } \\
\mathrm{N}=948\end{array}$} & \multirow[t]{2}{*}{ p-value } \\
\hline & $\begin{array}{c}\text { Preschool }^{1} \\
\mathrm{~N}=236 \\
(24.9 \%)\end{array}$ & $\begin{array}{c}\text { School } \\
\text { going } \\
\text { children }^{2} \\
\mathrm{~N}=235 \\
(24.8 \%)\end{array}$ & $\begin{array}{c}\text { Adolescent }^{3} \\
\mathrm{~N}=242 \\
(25.5 \%)\end{array}$ & $\begin{array}{c}\text { Adult }^{4} \\
\mathrm{~N}=235 \\
(24.8 \%)\end{array}$ & & \\
\hline \multicolumn{7}{|c|}{ Packed chips, fried nuts/peas and chanachur } \\
\hline Chips & $123(52.1)$ & $131(55.7)$ & $88(36.4)$ & $19(8.1)$ & $361(38.0)$ & 0.000 \\
\hline Chanachur & $99(41.9)$ & $122(51.9)$ & $100(41.3)$ & $54(23.0)$ & $375(39.6)$ & 0.000 \\
\hline Fried pulses/peas & $33(14.0)$ & $58(24.7)$ & $60(24.8)$ & $18(7.7)$ & $169(17.8)$ & 0.000 \\
\hline Muri (Puffed rice) & $93(39.4)$ & $112(47.7)$ & $122(50.4)$ & $112(47.7)$ & $439(46.3)$ & 0.089 \\
\hline \multicolumn{7}{|c|}{ Biscuits. Cakes and chocolate/lozenge } \\
\hline Unbranded salty biscuit & $9(3.8)$ & $9(3.8)$ & $9(3.7)$ & $14(6)$ & $41(4.3)$ & 0.569 \\
\hline
\end{tabular}




\begin{tabular}{|c|c|c|c|c|c|c|}
\hline Unbranded sweet biscuit & $14(5.9)$ & $21(8.9)$ & $15(6.2)$ & $21(8.9)$ & $71(7.5)$ & 0.419 \\
\hline Small packet biscuit & $82(34.7)$ & $72(30.6)$ & $54(22.3)$ & $23(9.8)$ & $231(24.4)$ & 0.000 \\
\hline Large Packet biscuit & $62(26.3)$ & $61(26)$ & $59(24.4)$ & $53(22.6)$ & $235(24.8)$ & 0.777 \\
\hline Unbranded cake & $76(32.2)$ & $74(31.5)$ & $52(21.5)$ & $34(14.5)$ & $236(24.9)$ & 0.000 \\
\hline Branded cake & $28(11.9)$ & $21(8.9)$ & $27(11.2)$ & $12(5.1)$ & $88(9.3)$ & 0.051 \\
\hline Chocolate/Lollipop/Lozenge & $107(45.3)$ & $99(42.1)$ & $61(25.2)$ & $5(2.1)$ & $272(28.7)$ & 0.000 \\
\hline \multicolumn{7}{|c|}{ Soft drinks, energy drinks, fruit drinks, and ice-creams } \\
\hline Soft drink & $35(14.8)$ & $47(20)$ & $72(29.8)$ & $62(26.4)$ & $216(22.8)$ & 0.000 \\
\hline Energy drink & $11(4.7)$ & $8(3.4)$ & $40(16.5)$ & $10(4.3)$ & $69(7.3)$ & 0.000 \\
\hline Fruit juice (packet) & $63(26.7)$ & $63(26.8)$ & $53(21.9)$ & $33(14.0)$ & $212(22.4)$ & 0.002 \\
\hline Unbranded ice-cream & $104(44.1)$ & $106(45.1)$ & $67(27.7)$ & $37(15.7)$ & $314(33.1)$ & 0.000 \\
\hline Branded ice-cream & $34(14.4)$ & $38(16.2)$ & $59(24.4)$ & $23(9.8)$ & $154(16.2)$ & 0.000 \\
\hline \multicolumn{7}{|c|}{ Locally produced deep fat fried and sweet snacks } \\
\hline Peyaju & $78(33.1)$ & $83(35.3)$ & $115(47.5)$ & $104(44.3)$ & $380(40.1)$ & 0.002 \\
\hline Beguni & $60(25.4)$ & $69(29.3)$ & $88(36.4)$ & $76(32.3)$ & $293(30.9)$ & 0.056 \\
\hline Puri/Moglai/Nimki & $22(9.3)$ & $33(14.0)$ & $34(14.0)$ & $42(17.9)$ & $131(13.8)$ & 0.191 \\
\hline Singara & $16(6.8)$ & $26(11)$ & $22(9.0)$ & $16(6.8)$ & $80(8.4)$ & 0.275 \\
\hline Alur chop & $3(1.3)$ & $5(2.1)$ & $12(4.9)$ & $12(5.1)$ & $32(3.4)$ & 0.039 \\
\hline Somucha & $1(0.42)$ & $2(0.85)$ & $3(1.2)$ & $5(2.1)$ & $11(1.1)$ & 0.356 \\
\hline \multicolumn{7}{|c|}{ Sweetmeat } \\
\hline Roshogolla & $10(4.2)$ & $8(3.4)$ & $5(2.1)$ & $9(3.8)$ & $32(3.4)$ & 0.581 \\
\hline $\begin{array}{l}\text { Sweetmeat } \\
\text { (kalojam/Golapjam) }\end{array}$ & $38(16.1)$ & $41(17.4)$ & $47(19.4)$ & $41(17.4)$ & $167(17.6)$ & 0.819 \\
\hline Jilapi & $66(28)$ & $69(29.4)$ & $79(32.6)$ & $79(33.6)$ & 293(30.9) & 0.499 \\
\hline \multicolumn{7}{|c|}{ Confectionary and other items } \\
\hline Chola (fried chickpea) & $20(8.5)$ & $24(10.2)$ & $38(15.7)$ & $43(18.3)$ & $125(13.2)$ & 0.007 \\
\hline Pastry/Cream-roll & $0(0)$ & $3(1.3)$ & $3(1.2)$ & $2(0.9)$ & $8(0.8)$ & 0.394 \\
\hline $\begin{array}{l}\text { Pizza/Burger/ Sandwich/ } \\
\text { Chicken Nugget }\end{array}$ & $3(1.3)$ & $39(1.3)$ & $12(5.0)$ & $7(3.0)$ & $25(2.6)$ & 0.035 \\
\hline Chutney & 21(8.9) & $39(16.6)$ & $32(13.2)$ & $6(2.6)$ & $98(10.3)$ & 0.000 \\
\hline Instant Noodles & $31(13.1)$ & $34(14.5)$ & $29(12)$ & $18(7.7)$ & $112(11.8)$ & 0.117 \\
\hline
\end{tabular}

\section{Food consumption pattern before and during Ramadan}

RtE food consumption patterns during and before Ramadan among the four categories of respondents were analyzed. It was found that the pattern significantly changed during Ramadan. The percent intake of puffed rice, peyaju, beguni, jilapi, branded ice cream was significantly high $(p<0.05)$ during Ramadan, whereas the consumption of chips, chanachur, fried peas and pulse, biscuits (small and large packet), branded and unbranded cake, chocolate/lollipop/lozenge, chutney, and puri were significantly high before Ramadan. Table 4 summarizes the results. 
Table 4. Consumption pattern of processed food and beverages before and during Ramadan.

\begin{tabular}{|c|c|c|c|}
\hline Intake frequency & $\begin{array}{c}\text { Prior Ramadan } \\
\mathbf{N}(\%) \\
\end{array}$ & $\begin{array}{c}\text { During Ramadan } \\
\mathbf{N}(\%) \\
\end{array}$ & p-value \\
\hline Chips & $209(41.0)$ & $143(32.6)$ & 0.005 \\
\hline Chanachur & $270(52.9)$ & $135(30.8)$ & 0.00 \\
\hline Peas/pulse fried & $110(21.6)$ & $70(16.0)$ & 0.019 \\
\hline Puffed rice & $176(34.5)$ & $224(51.1)$ & 0.0 \\
\hline Unbranded salty biscuit & $20(3.9)$ & $16(3.7)$ & 0.411 \\
\hline Unbranded sweet biscuit & $45(8.8)$ & $33(7.5)$ & 0.413 \\
\hline Biscuit small packet & $153(30.0)$ & $95(21.7)$ & 0.004 \\
\hline Biscuit large packet & $158(31.0)$ & $80(18.3)$ & 0.00 \\
\hline Unbranded cake & $153(30.0)$ & $102(23.3)$ & 0.001 \\
\hline Branded cake & $62(12.2)$ & $33(7.5)$ & 0.023 \\
\hline Soft drinks & $102(20.0)$ & $100(22.8)$ & 0.228 \\
\hline Energy drink & $44(8.6)$ & $30(6.8)$ & 0.235 \\
\hline Fruit juice & $110(21.6)$ & $107(24.4)$ & 0.329 \\
\hline Chocolate/lollipop/logenze & $183(35.9)$ & $109(24.9)$ & 0.00 \\
\hline Chutney & $75(14.7)$ & $41(9.4)$ & 0.012 \\
\hline Instant Noodles & $57(11.2)$ & $56(12.8)$ & 0.446 \\
\hline Unbranded ice cream & $180(35.3)$ & $147(33.6)$ & 0.576 \\
\hline Branded ice cream & $58(11.4)$ & $75(17.1)$ & 0.011 \\
\hline Sweetmeat & $100(19.6)$ & $78(17.8)$ & 0.429 \\
\hline Jilapi & $82(16.1)$ & $171(39.0)$ & 0.00 \\
\hline Peyaju & $82(16.1)$ & $238(54.3)$ & 0.00 \\
\hline Beguni & $39(7.6)$ & 192(43.8) & 0.00 \\
\hline Puri/moglai/nimki & $77(15.1)$ & $47(10.7)$ & 0.047 \\
\hline Roshgolla & $17(3.3)$ & $18(4.1)$ & 0.527 \\
\hline Pastry/creamroll & $1(0.2)$ & $4(0.9)$ & 0.129 \\
\hline Pizza/burger & $9(1.8)$ & $13(3.0)$ & 0.22 \\
\hline
\end{tabular}

\section{Consumption pattern of ready-to-eat foods in urban and rural areas}

It was found that among the urban people consumption rate of chips, fried pulse or peas, unbranded salty biscuit, branded cake, chutney, instant noodles, branded ice cream, puri/moglai/nimki, roshogolla, pizza/burger, and beverages like soft drinks, energy drinks, and fruit juice was significantly higher than among the rural population $(\mathrm{p}<0.05)$. In general, the urban population was more inclined toward packeted branded processed foods than the rural population. Table 5 summarizes shows the difference between RtE food consumption patterns among the urban and rural population. 
Table 5. Consumption pattern of processed foods in urban and rural areas

\begin{tabular}{|l|c|c|c|}
\hline Intake frequency & $\begin{array}{c}\text { Urban } \\
\mathbf{N = 3 2 0} \\
\mathbf{N}(\mathbf{\%})\end{array}$ & $\begin{array}{c}\text { Rural } \\
\mathbf{N = 6 2 8} \\
\mathbf{N}(\mathbf{\%})\end{array}$ & p-value \\
\hline Chips & $151(47.2)$ & $205(32.6)$ & 0.00 \\
\hline Chanachur & $148(46.8)$ & $232(36.9)$ & 0.06 \\
\hline Peas/pulse fried & $92(28.7)$ & $98(15.6)$ & 0.00 \\
\hline Puffed rice & $124(38.8)$ & $283(45.1)$ & 0.063 \\
\hline Unbranded salty biscuit & $37(11.6)$ & $41(6.5)$ & 0.008 \\
\hline Unbranded sweet biscuit & $16(5.0)$ & $51(8.1)$ & 0.076 \\
\hline Small packet biscuit & $81(25.3)$ & $145(23.1)$ & 0.447 \\
\hline Large packet biscuit & $63(19.7)$ & $158(25.2)$ & 0.060 \\
\hline Unbranded cake & $89(27.8)$ & $160(25.5)$ & 0.440 \\
\hline Branded cake & $42(13.1)$ & $54(8.6)$ & 0.029 \\
\hline Soft drinks & $90(28.1)$ & $109(17.4)$ & 0.00 \\
\hline Energy drink & $53(16.6)$ & $37(5.9)$ & 0.00 \\
\hline Fruit juice & $83(25.9)$ & $119(18.9)$ & 0.013 \\
\hline Chocolate/lollipop/logenze & $98(30.6)$ & $165(26.3)$ & 0.157 \\
\hline Chutney & $46(14.4)$ & $63(10.0)$ & 0.047 \\
\hline Instant Noodles & $59(18.4)$ & $58(9.2)$ & 0.00 \\
\hline Unbranded ice cream & $102(31.9)$ & $196(31.2)$ & 0.835 \\
\hline Branded ice cream & $92(28.7)$ & $65(10.4)$ & 0.00 \\
\hline Sweetmeat & $70(21.9)$ & $109(17.4)$ & 0.093 \\
\hline Jilapi & $96(30.0)$ & $186(29.6)$ & 0.903 \\
\hline Peyaju & $115(35.9)$ & $248(39.5)$ & 0.287 \\
\hline Beguni & $108(33.8)$ & $184(29.3)$ & 0.160 \\
\hline Puri/moglai/nimki & $63(19.7)$ & $76(12.1)$ & 0.002 \\
\hline Roshgolla & $20(6.3)$ & $21(3.3)$ & 0.038 \\
\hline Pastry/creamroll & $134(41.9)$ & $275(43.8)$ & 0.574 \\
\hline Pizza/burger & $67(20.9)$ & $82(13.1)$ & 0.002 \\
\hline & & & \\
\hline
\end{tabular}

\section{List of most commonly consumed ready-to-eat foods}

Table 6 shows the top ten most consumed food according to age group and residence type in non-Ramadan and Ramadan fasting periods. Among the pre-school children, chips were the prime choice and sweetmeat was the least consumed food before Ramadan whereas peyaju and unbranded cakes took the first and tenth place respectively during the Ramadan period. Among the school-going children, chips were the highest, and biscuit was the lowest consumed food regardless of the time period. Among adolescents, chanachur was the highest consumed food and soft drink was the lowest consumed food prior to Ramadan. However, the choices were replaced by Peyaju and fruit juice respectively during the Ramadan period.
Among adults, biscuit was the highest consumed food and jilapi was the lowest consumed food during the non-Ramadan period while peyaju was the highest and puri was the lowest consumed food during Ramadan period.

Resident-wise, chanachur was the highest consumed food in both rural and urban areas during the non-Ramadan period. On the other hand, biscuits and soft drinks were the lowest consumed food in both rural and urban areas during the nonRamadan period. During Ramadan, chips and peyaju were the first choices whereas, fried peas/pulse and chocolate/ lollipop/logenze were the last choice in urban and rural areas respectively. 
Table 6. Top foods according to food scoring before and during Ramadan

\begin{tabular}{|c|c|c|c|c|c|c|c|c|c|c|c|}
\hline \multicolumn{8}{|c|}{ Age category } & \multicolumn{4}{|c|}{ Residence category } \\
\hline \multicolumn{2}{|c|}{$2-5 Y$} & \multicolumn{2}{|c|}{$6-9 \mathrm{Y}$} & \multicolumn{2}{|c|}{$10-19 Y$} & \multicolumn{2}{|c|}{$\geq 20 Y$} & \multicolumn{2}{|c|}{ Urban } & \multicolumn{2}{|c|}{ Rural } \\
\hline NR & $\mathbf{R}$ & NR & $\mathbf{R}$ & NR & $\mathbf{R}$ & NR & $\mathbf{R}$ & NR & $\mathbf{R}$ & $\mathbf{N R}$ & $\mathbf{R}$ \\
\hline Chips & Peyaju & Chips & Chips & Chanachur & Peyaju & $\begin{array}{c}\text { Large Packet } \\
\text { Biscuit }\end{array}$ & Peyaju & Chanachur & Chips & Chanachur & Peyaju \\
\hline $\begin{array}{l}\text { Chocolate/Loll } \\
\text { ipop/Logence }\end{array}$ & $\begin{array}{c}\text { Muri } \\
\text { (Puffed } \\
\text { Rice) } \\
\end{array}$ & $\begin{array}{c}\begin{array}{c}\text { Chocolate/L } \\
\text { ollipop/Loge } \\
\text { nce }\end{array} \\
\end{array}$ & $\begin{array}{l}\text { Muri (Puffed } \\
\text { Rice) }\end{array}$ & $\begin{array}{c}\text { Muri (Puffed } \\
\text { Rice) }\end{array}$ & $\begin{array}{c}\text { Muri (Puffed } \\
\text { Rice) }\end{array}$ & $\begin{array}{l}\text { Muri (Puffed } \\
\text { Rice) }\end{array}$ & $\begin{array}{l}\text { Muri (Puffed } \\
\text { Rice) }\end{array}$ & Chips & Beguni & Chips & $\begin{array}{l}\text { Muri (Puffed } \\
\text { Rice) }\end{array}$ \\
\hline $\begin{array}{c}\text { Unbranded Ice } \\
\text { Cream }\end{array}$ & $\begin{array}{c}\text { Unbranded } \\
\text { Ice Cream }\end{array}$ & $\begin{array}{l}\text { Unbranded } \\
\text { Ice Cream }\end{array}$ & Peyaju & Chips & Beguni & Soft drinks & Beguni & $\begin{array}{c}\text { Muri (Puffed } \\
\text { Rice) }\end{array}$ & Peyaju & $\begin{array}{l}\text { Chocolate/Lol } \\
\text { lipop/Logence }\end{array}$ & Beguni \\
\hline Chanachur & Chips & Chanachur & $\begin{array}{c}\text { Unbranded Ice } \\
\text { Cream }\end{array}$ & $\begin{array}{c}\text { Fried } \\
\text { Peas/Pulse }\end{array}$ & Jilapi & $\begin{array}{c}\text { Sweetmeat } \\
\text { (kalojam,Gol } \\
\text { apjam) }\end{array}$ & Jilapi & $\begin{array}{c}\text { Small packet } \\
\text { biscuit }\end{array}$ & Chanachur & $\begin{array}{c}\text { Large Packet } \\
\text { Biscuit }\end{array}$ & Jilapi \\
\hline $\begin{array}{c}\text { Small packet } \\
\text { biscuit }\end{array}$ & $\begin{array}{c}\text { Chocolate/ } \\
\text { Lollipop/Lo } \\
\text { gence }\end{array}$ & $\begin{array}{l}\text { Muri (Puffed } \\
\text { Rice) }\end{array}$ & Chanachur & $\begin{array}{c}\text { Large Packet } \\
\text { Biscuit }\end{array}$ & Chips & Peyaju & Soft drinks & $\begin{array}{l}\text { Chocolate/Lol } \\
\text { lipop/Logence }\end{array}$ & $\begin{array}{l}\text { Muri (Puffed } \\
\text { Rice) }\end{array}$ & $\begin{array}{l}\text { Unbranded } \\
\text { Ice Cream }\end{array}$ & $\begin{array}{c}\text { Unbranded Ice } \\
\text { Cream }\end{array}$ \\
\hline $\begin{array}{c}\text { Unbranded } \\
\text { cake }\end{array}$ & Beguni & $\begin{array}{c}\text { Small packet } \\
\text { biscuit }\end{array}$ & Beguni & $\begin{array}{l}\text { Chocolate/Lol } \\
\text { lipop/Logence }\end{array}$ & Chanachur & Chips & $\begin{array}{c}\text { Fruit } \\
\text { Juice(Packet) }\end{array}$ & $\begin{array}{c}\text { Unbranded } \\
\text { cake }\end{array}$ & $\begin{array}{c}\text { Branded ice } \\
\text { cream }\end{array}$ & $\begin{array}{c}\text { Unbranded } \\
\text { cake }\end{array}$ & Chips \\
\hline $\begin{array}{c}\text { Large Packet } \\
\text { Biscuit }\end{array}$ & Chanachur & $\begin{array}{c}\text { Unbranded } \\
\text { cake }\end{array}$ & $\begin{array}{c}\text { Chocolate/Lolli } \\
\text { pop/Logence }\end{array}$ & $\begin{array}{c}\text { Unbranded Ice } \\
\text { Cream }\end{array}$ & Soft drinks & $\begin{array}{l}\text { Puri/Muglai/ } \\
\text { Nimki }\end{array}$ & $\begin{array}{c}\text { Sweetmeat } \\
\text { (kalojam,Gol } \\
\text { apjam) }\end{array}$ & $\begin{array}{l}\text { Unbranded } \\
\text { Ice Cream }\end{array}$ & Jilapi & $\begin{array}{c}\text { Muri (Puffed } \\
\text { Rice) }\end{array}$ & Chanachur \\
\hline $\begin{array}{c}\text { Fruit Juice } \\
\text { (Packet) }\end{array}$ & Jilapi & $\begin{array}{c}\text { Fruit } \\
\text { Juice(Packet) }\end{array}$ & Jilapi & $\begin{array}{c}\text { Unbranded } \\
\text { cake }\end{array}$ & $\begin{array}{l}\text { Unbranded } \\
\text { Ice Cream }\end{array}$ & $\begin{array}{c}\text { Unbranded } \\
\text { cake }\end{array}$ & $\begin{array}{l}\text { Unbranded } \\
\text { Ice Cream }\end{array}$ & $\begin{array}{c}\text { Fried } \\
\text { Peas/Pulse }\end{array}$ & Soft drinks & $\begin{array}{c}\text { Small packet } \\
\text { biscuit }\end{array}$ & $\begin{array}{c}\text { Unbranded } \\
\text { cake }\end{array}$ \\
\hline $\begin{array}{c}\text { Muri (Puffed } \\
\text { Rice) }\end{array}$ & $\begin{array}{l}\text { Small } \\
\text { packet } \\
\text { biscuit }\end{array}$ & $\begin{array}{c}\text { Fried } \\
\text { Peas/Pulse }\end{array}$ & Unbranded cake & $\begin{array}{c}\text { Small packet } \\
\text { biscuit }\end{array}$ & $\begin{array}{c}\text { Branded ice } \\
\text { cream }\end{array}$ & $\begin{array}{l}\text { Unbranded } \\
\text { Ice Cream }\end{array}$ & $\begin{array}{c}\text { Unbranded } \\
\text { cake }\end{array}$ & $\begin{array}{c}\text { Fruit } \\
\text { Juice(Packet) }\end{array}$ & $\begin{array}{l}\text { Unbranded } \\
\text { Ice Cream }\end{array}$ & $\begin{array}{c}\text { Fried } \\
\text { Peas/Pulse }\end{array}$ & $\begin{array}{c}\text { Small packet } \\
\text { biscuit }\end{array}$ \\
\hline $\begin{array}{c}\text { Sweetmeat } \\
\text { (kalojam,Gola } \\
\text { pjam) }\end{array}$ & $\begin{array}{c}\text { Unbranded } \\
\text { cake }\end{array}$ & $\begin{array}{c}\text { Large Packet } \\
\text { Biscuit }\end{array}$ & $\begin{array}{c}\text { Small packet } \\
\text { biscuit }\end{array}$ & Soft drinks & $\begin{array}{c}\text { Fruit } \\
\text { Juice(Packet) }\end{array}$ & Jilapi & $\begin{array}{l}\text { Puri/Muglai/ } \\
\text { Nimki }\end{array}$ & $\begin{array}{c}\text { Large Packet } \\
\text { Biscuit }\end{array}$ & $\begin{array}{c}\text { Fried } \\
\text { Peas/Pulse }\end{array}$ & Soft drinks & $\begin{array}{c}\text { Chocolate/Lolli } \\
\text { pop/Logence }\end{array}$ \\
\hline
\end{tabular}

NR-Non-Ramadan Month; R-Ramadan Fasting Month 


\section{Discussion}

We have identified a wide variety of processed RtE foods that are consumed in the rural and urban areas of Bangladesh. Such foods include Chips, Chanachur, unlabeled Ice-cream, Chocolate, Lozenge, Lollipop, Cake, labeled and unlabeled biscuits, beverages, and deep-fried savory snacks, etc. We have also identified a significant difference in consumption trend of these foods among different age groups, between urban and rural populations, and during the month of Ramadan and the non-Ramadan period. Among the overall population, highly consumed foods were puffed rice, peyaju, chanachur, chips, unbranded ice cream, beguni, jilapi, chocolate/lollipop/lozenge, unbranded cake, large biscuit. In an earlier study on the processed food intake among 36 months old children in Bangladesh, it was found that 70 percent of children consumed biscuits, 39\% of children consumed any kind of chocolate or lozenge, $33 \%$ consumed any kind of Bombay mix, 28\% consumed any form of sweets, $21 \%$ consumed chips and cake in the past 24 hours (Mridha, Hossain and Dewey, 2019). According to the present study sweet snacks (i.e. cake, roshgolla, chocolate, lozenge, and lollipop) were mostly consumed by pre-school children. This finding is in line with the previous findings. Among the school-going children, savory snacks like chips, chanachur, chutney, fried pulse consumption were prominent than other age groups. In a study of the 24-hour recall method among rural adolescents in Bangladesh, consumption of ultraprocessed sweets, confectionaries, and packaged products was $52 \%$ and consumption of savory snacks was around 35\% (Islam et al., 2020). According to this study, branded ice cream and sugar-sweetened beverages (soft drinks, energy drinks) were highly consumed by adolescents. This finding was in line with a previous finding where the consumption of sugar-sweetened beverages was found to be $13 \%$ among adolescents(Islam et al., 2020). The present study demonstrated that the adult population consumed puri, nimki, moglai, jilapi, alur chop more than other age groups. In a similar study among Bangladeshi university students, Singara, Samosa, Alur chop were the most common snacks among the students in a day's diet(Kabir, Miah and Islam, 2018).

We also divided the consumption rate in the rural-urban and before and during Ramadan month category for achieving a total scoring. It was found that among the urban population, the overall consumption rate of packaged items was higher than the rural population.

The percent intake of puffed rice, fried food (peyaju, beguni, jilapi), and branded ice creams were significantly high during Ramadan as compared to the non-Ramadan period ( $\mathrm{p}<0.05)$.In a study on dietary habits among women during Ramadan season in the Sylhet division of Bangladesh, consumption of fatty foods and sweets was found to be $97.5 \%$ and $89.3 \%$ higher respectively as compared to the non-Ramadan period (Seiermann et al., 2021).

Along with the increasing income and productivity, the Bangladeshi population has become busier and more urbanoriented during the last decade. In a study about the factors associated with consumer preference on fast food items in Bangladesh, it was found that the busy lifestyle led to more reliance on energy-dense snacks and beverages. Besides, increased availability of such foods in the market, roadside vendors, and restaurants may also contribute to the increase of consumption of these foods (Islam, 2010). Rana et al reported that aggressive marketing policy and advancement of advertising may also play a role in increasing the interest among children in these processed foods (Rana, M. B., Mowla, M. M., \& Islam, 2011). As these foods are mostly energy, sugar, and salt dense as well as oil fried, they have a very mouthwatering taste (Islam, 2010).

In an Indian study, snacks and sweets were found to contain very high energy $(136-603 \mathrm{kcal} / 100 \mathrm{gm})$ and trans fatty acid level (01-19.8\%) (Agrawal et al., 2008). In a study of labeled and unlabeled bakery products such as biscuits, pastries, cakes, puffs, samosa, instant noodles, etc., it was found that cake and puffs contained the highest energy, total fat, and trans fatty acid content in India (Reshma M. V., Ravi Kiran C., Nisha P., Soban Kumar D. R., Sundaresan A., 2012). Another study carried out in Pakistan to evaluate trans-fat contents in processed foods such as puri, cake, paratha, doughnuts, pastry/Cream roll, etc. available in the local market found the trans-fat content ranged between $6-38 \%$ with a particularly high content in doughnuts (38\%) and puri (18\%) (Shah et al., 2016). A comparative study on the packaged foods and beverages in 12 countries, found that middleincome countries like India and China fell behind in food healthiness according to the health star rating system (Dunford et al., 2019). Excessive sodium intake causes high blood pressure which causes one-tenth of CVD disease globally and is recognized as the $7^{\text {th }}$ leading factor behind worldwide mortality (WHO, 2012; Tursan D'espaignet, 2013). In India, cardiovascular disease causes 3 million death a year among which three-fourth are from hypertension (Gupta, 2004; Lim et al., 2012). The above studies demonstrated that most processed foods are rich in calorie, fat, and salt content. They are even rated as unhealthy in various south Asian countries. Many studies also found associations between energy-dense foods with diet-related non-communicable diseases. It is, therefore, important to identify and determine the consumption pattern of these foods from the health perspective of Bangladesh. It is also of utmost importance to know the nutrient composition of such foods in Bangladesh.

Previous studies on the trend of process food consumption in Bangladesh were carried out using a relatively small number of samples. As far our knowledge, this is the first study in which data were collected from all over the country and the nationwide trend in process food consumption could be inferred. Moreover, data were collected during non-Ramadan and the month of Ramadan when adult Muslims fast all day. This allows us to compare the processed food consumption trend during these two periods. However, though, most preschool and school-going children do not fast, yet all the household members usually take part in iftar in this culture. To avoid the over or underestimation to some extent, we scored the consumption rate of foods before and during Ramadan according to their age category and residence area separately. On the other hand, a relatively small number of household interviews from large city corporations were included in the present study, which may not be adequate to represent the consumption trend in these localities. 


\section{Conclusion}

$\mathrm{RtE}$ processed foods are associated with non-communicable diseases. To assess their healthiness and impact on public health, it is important to identify such foods and determine their consumption pattern in the population. In the present, we have identified $24 \mathrm{RtE}$ processed foods that are widely consumed in Bangladesh. We have also reported the consumption trend of these foods. Further studies are required to determine their nutrient composition and then their contribution to non-communicable diseases in Bangladesh. Such information will play a crucial role in formulating policies and guidelines regarding food control, preparation, and labeling to mitigate the health hazards associated with RtE process foods.

\section{Conflicts of interest}

The authors declare that they have no conflicts of interest.

\section{Acknowledgments}

The authors acknowledge the contribution of the field data collection team.

The present study was funded by the Directorate General of Health Services, Ministry of Health \& Family Welfare, Bangladesh, under its Non-Communicable Disease Control (NCDC) Program (Memo No. DGHS/LD/NCDC/Proc. Plan/GOB(Service)/2018-2019/SP-13/Negotiation/348,

Date:20.01.2019)

\section{References}

1. Agrawal, A. et al. (2008) 'High trans fatty acid content in common Indian fast foods', Nutrition and Food Science, 38(6), pp. 564-569. doi: 10.1108/00346650810920178.

2. Baker, P. and Friel, S. (2016) 'Food systems transformations, ultra-processed food markets and the nutrition transition in Asia', Globalization and Health, 12(1), p. 80. doi: 10.1186/s12992-016-0223-3.

3. Cahill, L. E. et al. (2014) 'Fried-food consumption and risk of type 2 diabetes and coronary artery disease: A prospective study in 2 cohorts of US women and men', American Journal of Clinical Nutrition, 100(2), pp. 667675. doi: 10.3945/ajcn.114.084129.

4. CDC (2010) The CDC Guide to Strategies for Reducing the Consumption of Sugar-Sweetened Beverages. Available at: https://stacks.cdc.gov/view/cdc/51532 (Accessed: 19 May 2021).

5. Department of Public Health and Primary Care, U. of C. (2013) High-risk hearts: a South Asian epidemic Department of Public Health and Primary Care.

6. Directorate General of Health Services, M. of H. and F. W. (2011) Strategic Plan for Surveillance and Prevention of Noncommunicable Diseases in Bangladesh 2011-2015.

7. Djoussé, L., Petrone, A. B., and Michael Gaziano, J. (2015) 'Consumption of fried foods and risk of heart failure in the physicians' health study', Journal of the American Heart Association, 4(4). doi: 10.1161/JAHA.114.001740.

8. Dunford, E. K. et al. (2019) 'A comparison of the healthiness of packaged foods and beverages from 12 countries using the Health Star Rating nutrient profiling system, 2013-2018', Obesity Reviews. doi: 10.1111/obr.12879.
9. Gupta, P. et al. (2019a) 'Indian Academy of Pediatrics Guidelines on the Fast and Junk Foods, Sugar Sweetened Beverages, Fruit Juices, and Energy Drinks', Indian Pediatrics, 56(9), pp. 849-863. doi: 10.1007/s13312-0191612-5.

10. Gupta, P. et al. (2019b) 'Indian Academy of Pediatrics Guidelines on the Fast and Junk Foods, Sugar Sweetened Beverages, Fruit Juices, and Energy Drinks', Indian Pediatrics, 56(9), pp. 849-863. doi: 10.1007/s13312-019. 1612-5.

11. Gupta, R. (2004) 'Trends in hypertension epidemiology in India', Journal of Human Hypertension. J Hum Hypertens, pp. 73-78. doi: 10.1038/sj.jhh.1001633.

12. Imamura, F. et al. (2015) 'Dietary quality among men and women in 187 countries in 1990 and 2010: A systematic assessment', The Lancet Global Health, 3(3), pp. e132e142. doi: 10.1016/S2214-109X(14)70381-X.

13. Islam, M. R. et al. (2020) 'Exploring Rural Adolescents' Dietary Diversity and Its Socioeconomic Correlates: A Cross-Sectional Study from Matlab, Bangladesh', Nutrients, 12(8), p. 2230. doi: 10.3390/nu12082230.

14. Islam, N. (2010) 'Factors Affecting Consumers' Preferences On Fast Food Items In Bangladesh', The Journal of Applied Business Research, 26(4), pp. 131146.

15. Jannat, K. et al. (2020) 'Snack food consumption among Bangladeshi children, supplementary data from a large RCT', Maternal and Child Nutrition, 16(4), p. 16. doi: 10.1111/mcn.12994.

16. Kabir, A., Miah, S., and Islam, A. (2018) 'Factors influencing eating behavior and dietary intake among resident students in a public university in Bangladesh: A qualitative study', PLoS ONE, 13(6). doi: 10.1371/journal.pone.0198801.

17. Lim, S. S. et al. (2012) 'A comparative risk assessment of burden of disease and injury attributable to 67 risk factors and risk factor clusters in 21 regions, 1990-2010: A systematic analysis for the Global Burden of Disease Study 2010', The Lancet, 380(9859), pp. 2224-2260. doi: 10.1016/S0140-6736(12)61766-8.

18. Mridha, M., Hossain, M. and Dewey, K. (2019) 'Processed Food Consumption Among 36 Mo-old Children in Rural Bangladesh (P11-088-19)', Current Developments in Nutrition, 3(Supplement_1). doi: 10.1093/cdn/nzz048.p11-088-19.

19. National Health and Medical Research Council (2013) Australian Dietary Guidelines.

20. Poti, J. M. et al. (2016) 'Highly processed and ready-toeat packaged food and beverage purchases differ by race/ethnicity among US households', Journal of Nutrition, 146(9), pp. 1722-1730. doi: 10.3945/jn.116.230441.

21. Rana, M. B., Mowla, M. M., \& Islam, M. T. (2011) 'Key success factors creating values in Marketing: a study on Instant-Food-Products (IFPs) marketing in Bangladesh', Indonesian Management \& Accounting Research, 10(1), pp. 19-39.

22. Ranganadham M., Sathish Kumar M. H., Devraja H. C., G. F. C. (2016) Traditional Dairy Products- ICAR ECourse Book. AgriMoon.com. Available at: https://agrimoon.com/traditional-dairy-products/. 
23. Reshma M. V., Ravi Kiran C., Nisha P., SobanKumar D. R., Sundaresan A., J. P. (2012) 'Trans fat content in labeled and unlabelled Indian bakery products including fried snacks', International Food Research Journal, 19(4), pp. 1609-1614.

24. Seiermann, A. U. et al. (2021) 'Women's fasting habits and dietary diversity during Ramadan in rural Bangladesh', Maternal \& Child Nutrition, p. e13135. doi: 10.1111/mcn.13135.

25. Shah, F. et al. (2016) 'Determination of trans fat in traditional Pakistani breakfast and snack foods', International Food Research Journal, 23(2), pp. 849-853.

26. Slimani, N. et al. (2009) 'Contribution of highly industrially processed foods to the nutrient intakes and patterns of middle-aged populations in the European prospective investigation into cancer and nutrition study', European Journal of Clinical Nutrition, 63, pp. S206S225. doi: 10.1038/ejcn.2009.82.

27. Stuckler, D. et al. (2012) 'Manufacturing Epidemics: The Role of Global Producers in Increased Consumption of Unhealthy Commodities Including Processed Foods,
Alcohol, and Tobacco', PLoS Medicine, 9(6), p. e1001235. doi: 10.1371/journal.pmed.1001235.

28. Sun, Y. et al. (2019) 'Association of fried food consumption with all cause, cardiovascular, and cancer mortality: Prospective cohort study', BMJ (Online), 364. doi: $10.1136 / \mathrm{bmj} . \mathrm{k} 5420$.

29. Tursan D'espaignet, E. (2013) Global NCD Action Plan 2013-2020 WHO WHO Health Statistics: Applied through the lens of the Global Monitoring Framework for the Prevention and Control of Noncommunicable Diseases Prevention of Noncommunicable Diseases World Health Organization tursandesp.

30. Watson, W. L. et al. (2016) 'Variations in serving sizes of Australian snack foods and confectionery', Appetite, 96, pp. 32-37. doi: 10.1016/j.appet.2015.08.042.

31. WHO (2012) Sodium intake for adults and children. Available at: https://www.who.int/publications/i/item/9789241504836.

32. WHO (2021) WHO global sodium benchmarks for different food categories. Available at: https://www.who.int/publications/i/item/9789240025097. 